\title{
Article
}

\section{Lean Maturity Assessment in ETO Scenario}

\author{
Mariastella Chiera (D), Francesco Lupi *, Andrea Rossi and Michele Lanzetta (D) \\ Department of Civil and Industrial Engineering, University of Pisa, 56122 Pisa, Italy; \\ mstella.chiera@gmail.com (M.C.); andrea.rossi1@unipi.it (A.R.); lanzetta@unipi.it (M.L.) \\ * Correspondence: francesco.lupi@ing.unipi.it; Tel.: +39-347-8530753
}

check for

updates

Citation: Chiera, M.; Lupi, F.; Rossi, A.; Lanzetta, M. Lean Maturity Assessment in ETO Scenario. Appl. Sci. 2021, 11, 3833. https://doi.org/ 10.3390/app11093833

Academic Editor: Maurizio Faccio

Received: 15 March 2021

Accepted: 19 April 2021

Published: 23 April 2021

Publisher's Note: MDPI stays neutral with regard to jurisdictional claims in published maps and institutional affiliations.

Copyright: (c) 2021 by the authors. Licensee MDPI, Basel, Switzerland. This article is an open access article distributed under the terms and conditions of the Creative Commons Attribution (CC BY) license (https:// creativecommons.org/licenses/by/ $4.0 /)$.
Abstract: The obligatory path towards a lean manufacturing organization requires assessment and monitoring. However, a lean assessment framework is not yet available for the engineer to order (ETO) scenario. This work explored ten lean ETO maturity principles-identified from the literaturethat take insight from three formally defined sets (Toyota Way, lean construction, and lean product development principles). A practical assessment model was proposed based on the evaluation of ten lean ETO objective criteria (four with mathematical formulation) and was validated on a real industrial case. A problem-solving tool, including a new lean tool, called the Problem Focus Matrix (PFM), was also presented; this tool was aimed toward development of an integrated framework that would include the organization mission, management, and continuous improvement.

Keywords: lean production; engineer to order (ETO); lean assessment; continuous improvement

\section{Introduction}

According to Womack's definition from the 1990s, lean production (or lean manufacturing) is a set of methods and tools to identify and eliminate inefficiencies and waste at the enterprise and manufacturing level without requiring additional resources [1].

This work proposes a theoretical lean maturity assessment model, along with its application to a real case study, in the specific context of engineer to order (ETO).

A graphical representation of the paper structure is provided in Figure 1.

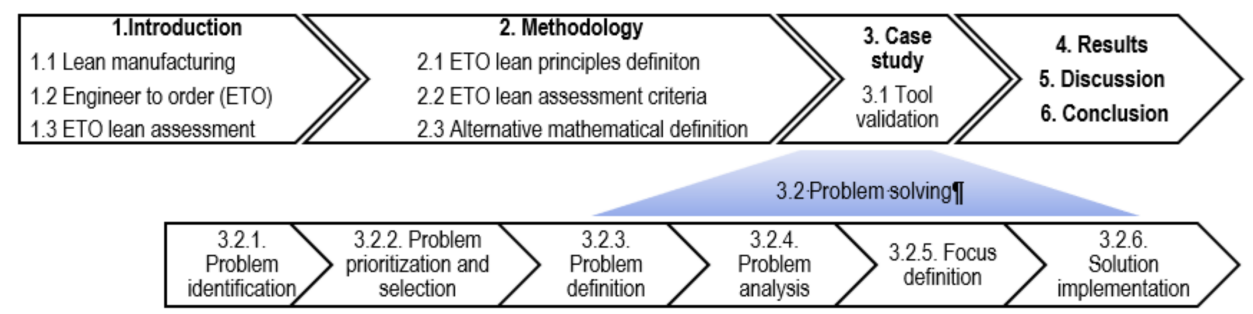

Figure 1. Graphical paper outline. The assessment model described in Section 2 is developed, starting from the background in Section 1. It is further detailed and validated on a real case study in 3, using an improvement process based on problem solving.

Background information on lean manufacturing and ETO is presented in Sections 1.1 and 1.2, respectively. The relevant literature on both is reported in Section 1.3, focusing on the ETO lean maturity assessment. Section 2 describes the methods used in the formal definition of the ten lean principles retrieved from the literature and the generation of the ETO lean assessment model using ten relative criteria. In Section 3, the assessment model is further detailed and validated on a real case study. A problem-solving approach based on the evidence, which emerged in the application of the model, is also presented. The main results and research perspectives are exposed in Sections 4 and 5, respectively. Conclusions can be found in Section 6. 


\subsection{Lean Manufacturing}

The culture of lean manufacturing was conceived and developed in the Toyota production system (TPS), pioneered by Japanese engineers Taiichi Ohno and Shigeo Shingo [2,3].

After World War II, Japanese manufacturers realized that they could not afford the massive investment required to rebuild devastated facilities. In response, they developed methods to produce automobiles with less inventory, human effort, and investment (and fewer defects), introducing a growing variety of products over time [2].

The modern concept of LM/management can also be attributed to the customized, integrated application of TQC [4]. Toyota was one of the first Japanese companies to implement statistical quality control, in 1949 [5].

The many well-known features of lean production include: bottleneck analysis [6], the Kanban system (the just-in-time (JIT) process) [7,8], kaizen (continuous improvement) $[9,10]$, value stream mapping (VSM) [11], lean six sigma [12-14], single minute exchange of die (SMED) [15], 5S [16], zero inventory [17], work standardization [18], and lean product development (LPD) [19]. The main goal behind this-and all related tools and techniques-concerns the improvement of the effectiveness and efficiency of the production process through deletion of waste (or muda) [20].

As accepted in the TPS, any manufacturing process is prone to seven types of waste: overproduction, inventory, transport, waiting times, movements, overprocessing, and defects [21,22]. In addition to this set, the underutilization of employee creativity is considered an eighth type of waste; environmental waste is considered a ninth [23].

The speed of Japan's production system methods' penetration into manufacturing industries all around the world demonstrated the significant relevance of their philosophy [2]. Half a century after the birth of the lean concept, despite all the context mutations, lean remains a trending phenomenon, often associated with industry 4.0 -and certainly included in sustainability [24,25].

\subsection{Engineer to Order (ETO)}

Lean manufacturing has been essentially developed in low-mix and high-volume repetitive push-based manufacturing industries (e.g., make to stock (MTS) [26] and assemble to order (ATO) [27]), yielding cost and lead time reduction, along with quality improvements. However, the increase of globalization, along with frequent recessions, has forced many organizations to reduce costs and to be more responsive to customer demands.

As shown in Figure 2, by moving the customer order decoupling point (CODP) to an ETO scenario, the implementation of lean strategies grows more challenging. Additionally, it extends beyond manufacturing alone, into pull-based (not standardized) systems [28], low-volume/high-mix methods, and one of a kind or highly customized parts, e.g., the building, construction, machinery, shipbuilding, aerospace and railway industries.

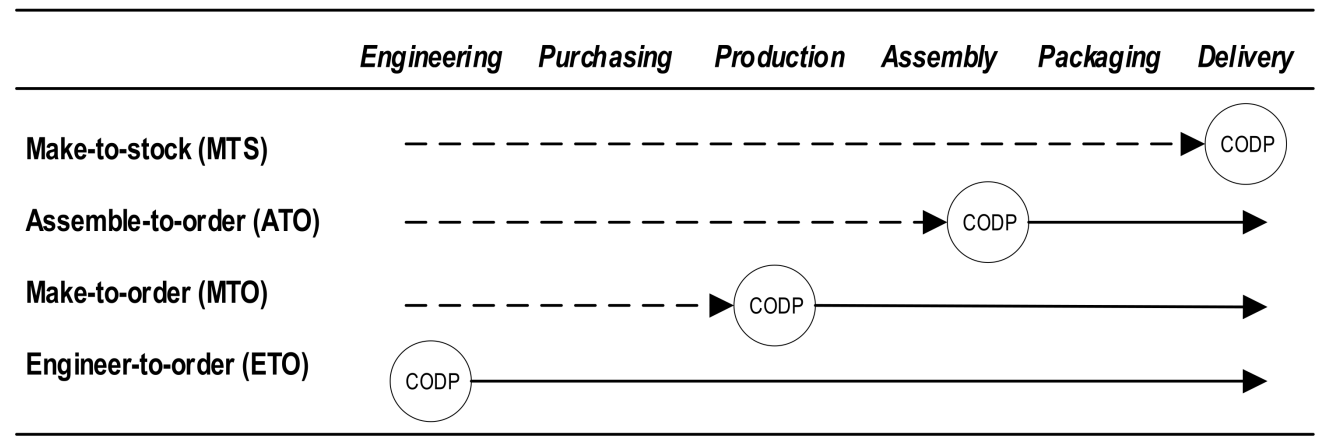

Figure 2. CODP, also known as freeze point or order penetration point. This refers to the point in the value chain at which a customer triggers a company's activities [28]. All activities before the CODP share a forecast-driven, push-based approach (dotted lines/arrows). Activities after the CODP are characterized by a customer-driven, pull based approach (continuous lines/arrows). 
From mass production to mass customization, the growing degree of personalization in production has focused efforts on selling margins, rather than on volume. This results in efficiency loss, which is unacceptable in highly competitive global markets [29]. This is a contributing factor to the growing interest in lean methods and tools in ETO organizations [29-31]. However, some barriers in the implementation of lean practices in an ETO scenario remain [32].

The purpose of this work was to define an assessment framework for the ETO scenario and provide an objective, absolute evaluation of the current lean maturity level. Additionally, the work purposed to monitor the evolution of lean methodologies within individual or multiple organizations.

\subsection{ETO Lean Assessment}

The culture of companywide assessment has grown more and more popular, leading to the diffusion of quality, health, safety, and environmental management protocols. One primary goal of this growing business culture is to measure system status with respect to given criteria, and enhance the system through feedback actions $[33,34]$. This paper benefitted from and contributes to the development of such culture.

A comprehensive review on the assessment of the implementation of lean practices within an organization can be found in [35]. Remarkable work has been carried out using quantitative, qualitative, and hybrid approaches to assess lean implementation and transformation (see [36-38]). The Leanness Assessment Tool (LAT) in [36] provided theoretical implications that helped us define the idea behind our presented model. In this work, the LAT was developed based on lean research, using both quantitative and qualitative dimensions to assess lean implementation. Among other contributions, one of the most rewarding was the Lean Enterprise Transformation Maturity Model (LESAT). This model is focused on assessing the degree of maturity of an enterprise by using lean principles and practices to achieve the best value for the enterprise and its stakeholders $[39,40]$.

In [41], a combination of lean and cloud manufacturing, used to provide a lean monitoring system in a i4.0 contemporary framework, was provided.

However, despite the numerous general assessment tools and theories available in the literature on lean assessment, more research for their application to ETO scenarios is required. In particular, it seems that a practical lean assessment method suited for ETO systems is not yet available.

The aim of this work was to propose a practical model specifically for ETO organizations. The proposed model offers various target uses (e.g., self-assessment, consulting, and third-party auditing) and can be applied at different improvement stages (e.g., identifying and prioritizing areas for improvement, benchmarking with other organizations, progress monitoring over time, and sharing organization-wide learning). The two primary ingredients on which the proposed assessment tool was built up were: the ten ETO principles stated in [30], and the ISO 9004:2018 standard for achieving sustained success self-evaluation tool [42].

As stated in [30], the new set of principles (listed in Table 1) aimed at enabling ETO manufacturers to pursue the lean ideal, gathered insight into lean production from the 14 principles of the Toyota Way [43], the 11 lean construction principles in [44], and the 13 lean product development principles in [45].

In Figure 3, these principles are clustered over Management, Processes, Products, and Stakeholders. It details how those principles concur on delivering value to the customer. In an ETO scenario, the customer demand triggers the system. In this framework, continuous improvement is the engine that feeds the organization, from a dynamic perspective.

The ISO 9004 self-auditing tool is based on five levels of assessment. This tool can clearly outline a high-level overview on management systems' effectiveness in accordance with regulatory standards. It allows the review of the organization's performance against specified criteria. It can also identify current maturity levels and determine strengths and 
weaknesses—with respect to management-in order to facilitate sustained organizational success. A similar approach was adopted within the ETO lean principles previously defined.

Table 1. The ten ETO lean principles from [30] with their Px. Abbreviation in bold font.

\begin{tabular}{cc}
\hline & ETO Lean Principles \\
\hline P1. & Defining Stakeholders Value \\
\hline P2. & Leadership, People and Learning \\
\hline P3. & Flexibility \\
\hline P4. & Modularization \\
\hline P5. & Continuous flow process \\
\hline P6. & Demand Pull \\
\hline P7. & Stakeholders and System Integration \\
\hline P8. & Transparency \\
\hline P9. & Technology \\
\hline P10. & Continuous Improvement
\end{tabular}

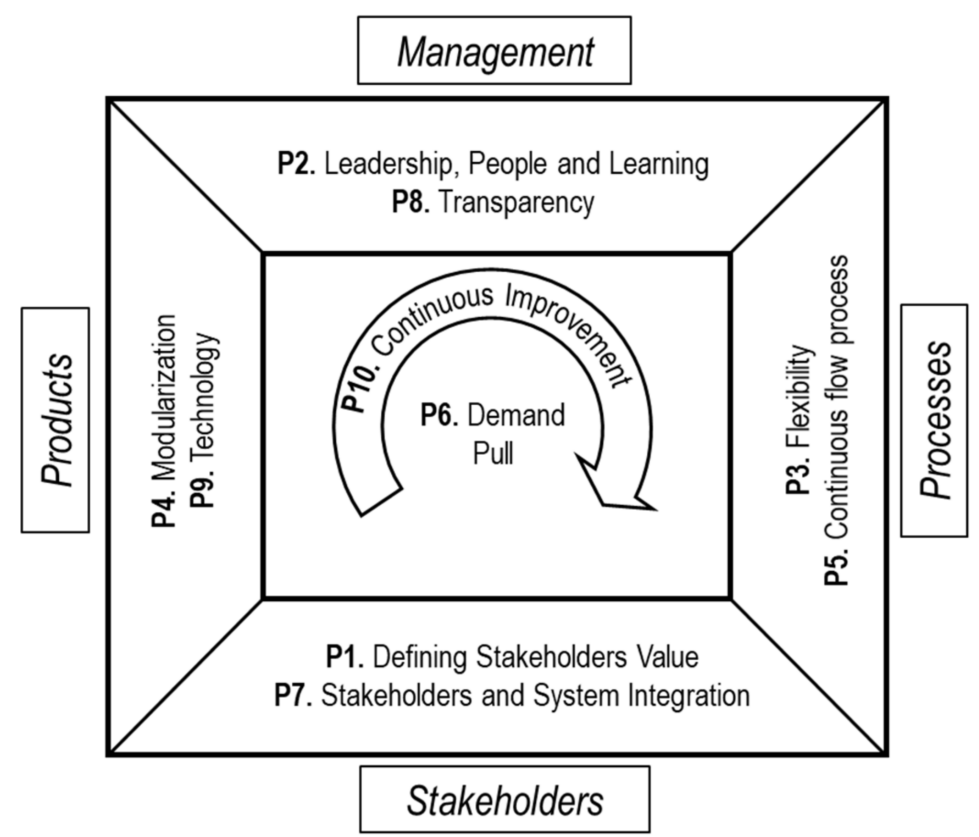

Figure 3. Map of ten ETO lean principles.

\section{Methodology}

This section describes the methodology used in the generation of the proposed ETO lean assessment tool, which is synthetically represented in Section 2.2.

Section 2.1 formally defines the ten ETO lean principles, identified in Section 1.3. Section 2.2. presents objective evaluation criteria arranged in the assessment tool. Section 2.3, defines mathematical criteria for four of the ten principles. In Figure 4, the logical flow of the methodology is shown, and the main steps are represented by light blue boxes.

\subsection{ETO Lean Principles Definition}

Ten principles have been stated and defined. For each of the principles, a synthetic review to extract relevant information for a formal definition has been offered. The purpose of this formal definition lies in the search for objective principles on which it would be possible to base assessments. 


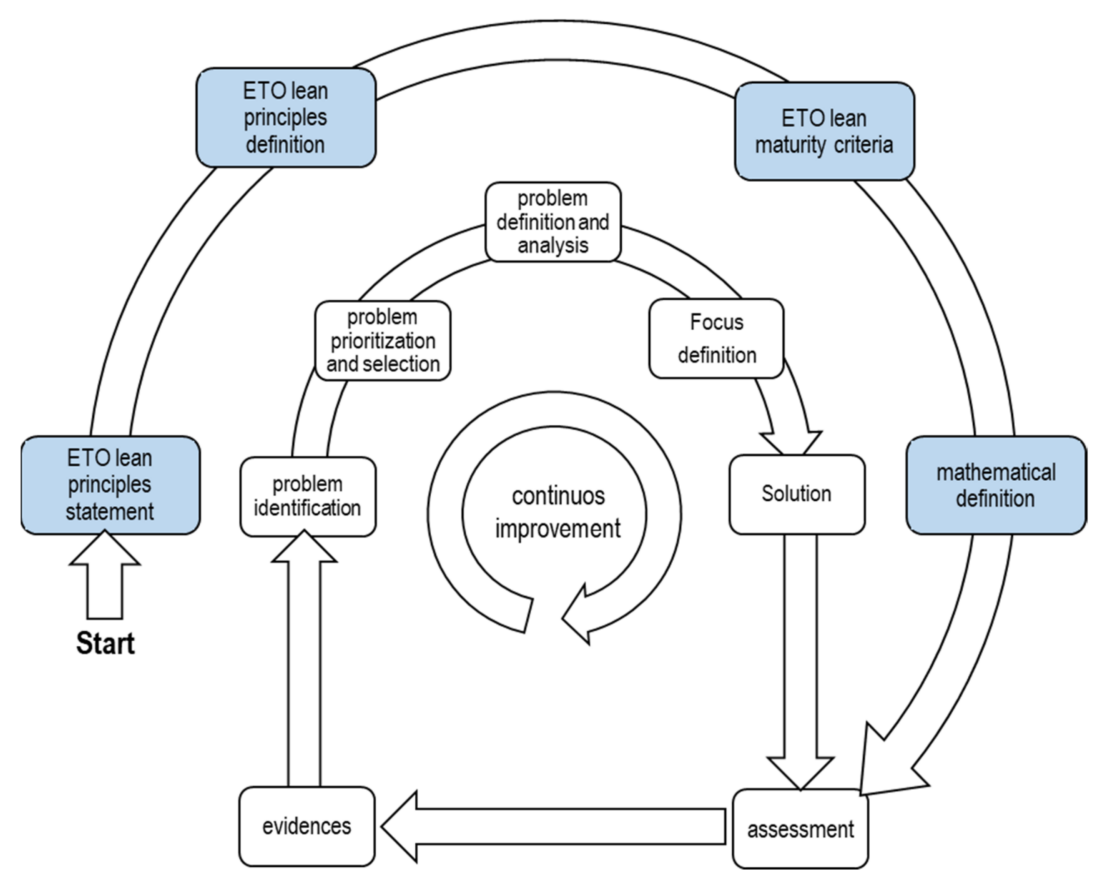

Figure 4. The two concentric virtuous loops concerning the (external) assessment model and the (internal) interested organization, respectively.

\subsubsection{P1. Defining Stakeholders Value}

The Stakeholders Value Analysis (SVA), developed by [46], is a methodology that provides a mechanism to define, link, and integrate the concerns of all stakeholders into a decision. The main steps characterizing the SVA methodology can be associated to the following five steps:

1. Identification of relevant stakeholders, including external (e.g., customers) and internal (e.g., employees and company owners) stakeholders. The identification process may result in a long list.

2. Identification and assignment of (key) performance attributes, called values, to the stakeholder group. In this step, the main values in which the stakeholders' groups are interested are defined.

3. Definition of value weights through the pairwise comparison model, stakeholders cluster method, or others. Weights for an attribute are determined simply, by comparing pairs of attributes one at a time.

4. Computation of a total value index for each option being assessed by the analysis. A cumulative score for each option is calculated.

5. Research an option that satisfies most of the main concerns of the stakeholders. Create of a new option, as well, possibly based on those originally considered.

The presented methodology is a representative example of a structured SVA process and can be considered a guideline in the evaluation of the maturity level of this specific principle.

\subsubsection{P2. Leadership, People and Learning}

Leadership is evaluated by the LESAT methodology [39,40], which is based on the following three macro topics, particularly the dominant one (i):

i. Transformation and change management,

ii. Product development, and

iii. Procedures for infrastructures.

People and learning is based on [47], in which an evaluation of the maturity level of Malaysian SMEs in industry 4.0 was carried out, strongly considering people's competences and the acquisition of lean concepts empowered throughout the organization. 


\subsubsection{P3. Flexibility}

In a perfectly lean and flexible production system, the lead time between customer demand and delivery would be zero. To quantitatively evaluate the maturity level of the flexibility principle, see Formula (1) from [48] for a mathematical definition in which the ratio of the deviation and the total demand were weighted by the capacity demand (more details in Section 2.3.1).

\subsubsection{P4. Modularization}

In [49], the authors presented a mathematical model for the evaluation of the modularization degree for a given product architecture. That definition has been adopted to quantitatively assess the lean maturity of the modularization principle. The amount of modularization is a function of new components, substitutability factor, and interface constraints (more details in Section 2.3.2).

\subsubsection{P5. Continuous Process Flow}

Numerous parameters for monitoring process flow continuity are available. In order to quantitatively and practically evaluate the lean maturity of the continuous process flow principle, for a mathematical definition, see Work in Progress (WIP) [50] (more details in Section 2.3.3).

\subsubsection{P6. Demand Pull}

As a matter of fact, ETO systems are pull-based. Moreover, demand pull is a basic lean manufacturing principle. In order to quantitatively evaluate maturity level-with regard to the organization phasing of customer requests-the relation between forward scheduling (push) and backward request (pull) in $\backslash$ product development and production was considered by [51] (more details in Section 2.3.4).

\subsubsection{P7. Stakeholders and Systems Integration}

Stakeholder integration can be related to either stakeholder management or management of stakeholders. The different forms of interaction between stakeholders and companies is a delicate topic, analyzed in depth in order to identify key factors that provide companies with competitive advantages. There is significant, relevant need for variables that allow the definition of a measurement scale for stakeholder integration [52].

A set of stakeholders' interaction indicators from [52] was considered. These were: knowledge (of the stakeholders and their demands), interaction (between stakeholders and company), and the adaptational behavior of the company toward their stakeholders.

\subsubsection{P8. Transparency}

At the organizational level, effective transparency is enacted through a company's willingness to consistently relay information to internal or external interested parties $[53,54]$. Thus, transparency assessments (in an organizational context) should consider the nature of the information provided by the organization. Clarity, for example, is identified as the amount of understandability perceived by the information receiver. That fact deserves significant attention $[53,55]$.

\subsubsection{P9. Technology}

In addition to the previously mentioned ETO lean principles (which serve a strict role in the transition of an organization from a practical hardware/software side), technology is the core of many industrial systems. It is thus, understandably, an important component of the engine of change. It is for this reason that the smart factory paradigm received so much attention [56]. For example, several technology enablers in manufacturing scenarios have penetrated almost every production system in place today, even ETO. These include CAE systems for design and simulation, advanced subtractive/additive manufacturing, 
sensors, programmable robots for material handling, automated quality control systems, ERP management systems, MES digital twins, and more. [57,58].

\subsubsection{P10. Continuous Improvement}

One of the quality pillar-continuous improvement-plays a key role in driving an organization toward better performance. It also impacts the creation of new opportunities. Numerous international quality management system standards (e.g., ISO 9001 [59]) have highlighted this concept as the propulsor of the Deming wheel $[21,60]$.

Among continuous improvement assessing models, the capability model proposed by [61] is considered a useful guide in efforts to define lean maturity. This model described continuous improvement in terms of a set of key behaviors or behavioral routines deemed essential for long-term success. In this framework, awareness of the major lean tools (highlighted in Section 1.1) was applied in a problem-solving approach.

\subsection{ETO Lean Assessment Criteria}

Table 2 summarizes the assessment criteria (over five maturity levels) for each of the ten ETO lean principles defined in Section 2.1. Levels or grades serve as alternatives to a continuous score (percentage), where mathematical expressions are available (Section 2.3).

Table 2. The ETO lean assessment $10 \times 5$ matrix. For each principle, the lean maturity level, grade, and score range (percentage) are compared in the table header. The criteria and mathematical formulas are derived from the definitions in Sections 2.1 and 2.2, respectively, according to the references, and are presented in the sections indicated in the last column. The principles labeled with ${ }^{*}$ ) denote a lack of a mathematical definition.

\begin{tabular}{|c|c|c|c|c|c|c|}
\hline $\begin{array}{l}\text { ETO Lean } \\
\text { Principles }\end{array}$ & \multicolumn{5}{|c|}{ Lean Maturity Criteria } & \multirow{4}{*}{$\begin{array}{l}\text { [Ref.], } \\
\text { (Section) }\end{array}$} \\
\hline Grade & 1 & 2 & 3 & 4 & 5 & \\
\hline Score & {$[0-20 \%)$} & {$[20-40 \%)$} & {$[40-60 \%)$} & {$[60-80 \%)$} & {$[80-100 \%)$} & \\
\hline Level & Negligible & Low & Medium & High & Full & \\
\hline P1. * & $\begin{array}{l}\text { (i) Stakeholders } \\
\text { identification }\end{array}$ & $\begin{array}{l}\text { (i) Identification and } \\
\text { assignment of the } \\
\text { (key) performance } \\
\text { attributes or values to } \\
\text { the stakeholder } \\
\text { group. }\end{array}$ & $\begin{array}{l}\text { (i) Definition of value } \\
\text { weights through } \\
\text { Pairwise Comparison } \\
\text { Model, Stakeholders } \\
\text { Cluster Method, or } \\
\text { others. }\end{array}$ & $\begin{array}{l}\text { (i) Calculation of a } \\
\text { total value index for } \\
\text { each option being } \\
\text { assessed by the } \\
\text { analysis. }\end{array}$ & $\begin{array}{l}\text { (i) Satisfaction of the } \\
\text { main concerns of the } \\
\text { stakeholders as well } \\
\text { as the creation of a } \\
\text { new option, possibly } \\
\text { based on those } \\
\text { originally considered. }\end{array}$ & $\begin{array}{c}\text { [46], } \\
\text { (Section 2.1.1) }\end{array}$ \\
\hline P2. * & $\begin{array}{l}\text { (i) Level of } \\
\text { commitment among } \\
\text { senior leaders and } \\
\text { management is } \\
\text { variable. Some } \\
\text { endorse, while others } \\
\text { may actively resist. } \\
\text { (ii) Employee } \\
\text { competencies are at } \\
\text { beginner level and } \\
\text { call for theoretical } \\
\text { training. }\end{array}$ & $\begin{array}{l}\text { (i) Senior } \\
\text { management buys } \\
\text { into group } \\
\text { commitment and } \\
\text { engages in the } \\
\text { transformation } \\
\text { process. (ii) Minimum } \\
\text { knowledge of lean } \\
\text { philosophy with } \\
\text { applications in } \\
\text { standard parts of the } \\
\text { production process. }\end{array}$ & $\begin{array}{l}\text { (i) Senior managers } \\
\text { personally and visibly } \\
\text { lead enterprise } \\
\text { transformation. (ii) } \\
\text { Complete knowledge } \\
\text { of lean principles } \\
\text { with application over } \\
\text { entire production } \\
\text { process, including } \\
\text { training on the job. }\end{array}$ & $\begin{array}{l}\text { (i) Senior leaders are } \\
\text { championing the } \\
\text { transformation within } \\
\text { the enterprise. (ii) } \\
\text { Conclusion training } \\
\text { on the job and } \\
\text { beginner } \\
\text { implementation of } \\
\text { lean techniques across } \\
\text { the entire company. }\end{array}$ & $\begin{array}{l}\text { (i) Senior leaders and } \\
\text { management mentor } \\
\text { and foster } \\
\text { transformation } \\
\text { champions internally } \\
\text { and throughout the } \\
\text { extended enterprise. } \\
\text { (ii) Complete } \\
\text { knowledge of lean } \\
\text { techniques at all the } \\
\text { company levels. }\end{array}$ & $\begin{array}{c}{[39,40,47]} \\
\text { (Section 2.1.2.) }\end{array}$ \\
\hline & \multicolumn{5}{|c|}{ Formula (1) } & \multirow[b]{2}{*}{$\begin{array}{c}\text { [48], } \\
\text { (Section 2.1.3.) } \\
\text { (Section 2.3.1.) }\end{array}$} \\
\hline P3. & $\begin{array}{l}\text { (i)Long lead times for } \\
\text { customization } \\
\text { (ii) Low capacity of } \\
\text { adaptation for } \\
\text { customers' needs. }\end{array}$ & $\begin{array}{l}\text { (i) Moderate lead } \\
\text { times for } \\
\text { customization. } \\
\text { (ii) Limited capacity } \\
\text { of adaptation for } \\
\text { customers' needs. }\end{array}$ & $\begin{array}{l}\text { (i) Average lead times } \\
\text { for customization } \\
\text { (high volumes and } \\
\text { mix). } \\
\text { (ii) Average capacity } \\
\text { of adaptation for } \\
\text { customers' needs. }\end{array}$ & $\begin{array}{l}\text { (i) Limited lead times } \\
\text { for customization } \\
\text { (ii) Moderate capacity } \\
\text { of adaptation for } \\
\text { customers' needs. }\end{array}$ & $\begin{array}{l}\text { (i) The lead time } \\
\text { between customer } \\
\text { demand dates } \\
\text { and production dates } \\
\text { are zero } \\
\text { (ii) Complete } \\
\text { flexibility of volumes } \\
\text { and mix. }\end{array}$ & \\
\hline & \multicolumn{5}{|c|}{ Formula (2) } & \multirow[b]{2}{*}{$\begin{array}{c}\text { [49], } \\
\text { (Section 2.1.4.) } \\
\text { (Section 2.3.2.) }\end{array}$} \\
\hline P4. & $\begin{array}{l}\text { Product architecture } \\
\text { is composed of new } \\
\text { components with low } \\
\text { replacement, allowing } \\
\text { customer minimum } \\
\text { mixing and matching. }\end{array}$ & $\begin{array}{l}\text { Product architecture } \\
\text { is composed of higher } \\
\text { numbers of new } \\
\text { components and } \\
\text { lower numbers of } \\
\text { standard components, } \\
\text { with limited } \\
\text { replacement degrees. }\end{array}$ & $\begin{array}{l}\text { Product architecture } \\
\text { is composed of both } \\
\text { new components and } \\
\text { standard components } \\
\text { with average } \\
\text { replacement degrees. }\end{array}$ & $\begin{array}{l}\text { Product architecture } \\
\text { is composed of lower } \\
\text { number of new } \\
\text { components and } \\
\text { higher numbers of } \\
\text { standard components, } \\
\text { with moderate } \\
\text { replacement degrees. }\end{array}$ & $\begin{array}{l}\text { Product architecture } \\
\text { is composed of } \\
\text { standard components } \\
\text { with higher } \\
\text { replacement degrees, } \\
\text { allowing clients } \\
\text { higher opportunities } \\
\text { for mixing and } \\
\text { matching. }\end{array}$ & \\
\hline
\end{tabular}


Table 2. Cont.

\begin{tabular}{|c|c|c|c|c|c|c|}
\hline $\begin{array}{l}\text { ETO Lean } \\
\text { Principles }\end{array}$ & & & Lean Maturity Criteria & & & \\
\hline Grade & 1 & 2 & 3 & 4 & 5 & $\begin{array}{c}\text { [Ref.], } \\
\text { (Section) }\end{array}$ \\
\hline Score & {$[0-20 \%)$} & {$[20-40 \%)$} & {$[40-60 \%)$} & {$[60-80 \%)$} & {$[80-100 \%)$} & \\
\hline Level & Negligible & Low & Medium & High & Full & \\
\hline \multirow[b]{2}{*}{ P5. } & \multicolumn{5}{|c|}{ Formula (3) } & \multirow[b]{2}{*}{$\begin{array}{c}{[50],} \\
\text { (Section 2.1.5.) } \\
\text { (Section 2.3.3.) }\end{array}$} \\
\hline & $\begin{array}{c}\text { Elevated WIP and } \\
\text { defects. }\end{array}$ & $\begin{array}{l}\text { Moderate level WIP } \\
\text { and defects }\end{array}$ & $\begin{array}{l}\text { Average level WIP } \\
\text { and defects. }\end{array}$ & $\begin{array}{c}\text { Low level WIP and } \\
\text { defects }\end{array}$ & $\begin{array}{c}\text { No WIP. The process } \\
\text { flow is continuous } \\
\text { without obstacles or } \\
\text { waste. }\end{array}$ & \\
\hline \multirow[b]{2}{*}{ P6. } & \multicolumn{5}{|c|}{ Formula (4) } & \multirow[b]{2}{*}{$\begin{array}{c}\text { [51], } \\
\text { (Section 2.1.6.) } \\
\text { (Section 2.3.4.) }\end{array}$} \\
\hline & $\begin{array}{l}\text { Order triggers } \\
\text { delivery. The prior } \\
\text { activities are } \\
\text { forecast-based. }\end{array}$ & $\begin{array}{l}\text { Order triggers } \\
\text { packaging. The prior } \\
\text { activities are } \\
\text { forecast-based }\end{array}$ & $\begin{array}{l}\text { Order triggers } \\
\text { assembly. The prior } \\
\text { activities are } \\
\text { forecast-based }\end{array}$ & $\begin{array}{l}\text { Order triggers } \\
\text { purchasing. The prior } \\
\text { activities are } \\
\text { forecast-based }\end{array}$ & $\begin{array}{l}\text { Order triggers } \\
\text { engineering; zero } \\
\text { activities are } \\
\text { forecast-driven }\end{array}$ & \\
\hline P7. * & $\begin{array}{l}\text { (i) The company } \\
\text { identified all the } \\
\text { stakeholders. } \\
\text { (ii) The company } \\
\text { frequently has } \\
\text { meetings with } \\
\text { thestakeholders. }\end{array}$ & $\begin{array}{l}\text { (i)The company } \\
\text { consults the } \\
\text { stakeholders and asks } \\
\text { them for information } \\
\text { before making } \\
\text { decisions. }\end{array}$ & $\begin{array}{l}\text { (i) The company's } \\
\text { formal or informal } \\
\text { cooperation with the } \\
\text { stakeholders is } \\
\text { intense } \\
\text { (commitments, } \\
\text { collaboration } \\
\text { agreements, etc.) }\end{array}$ & $\begin{array}{l}\text { (i) Stakeholder } \\
\text { participation in the } \\
\text { company's decisions } \\
\text { is formal and includes } \\
\text { quantitatively } \\
\text { relevant information. }\end{array}$ & $\begin{array}{l}\text { The company: (i) } \\
\text { strives to develop } \\
\text { new contacts with all } \\
\text { stakeholders, and (ii) } \\
\text { dedicates time and } \\
\text { resources to assessing } \\
\text { and prioritizing the } \\
\text { demands of the } \\
\text { different } \\
\text { stakeholders. }\end{array}$ & $\begin{array}{c}{[51,52],} \\
\text { (Section 2.1.7.) }\end{array}$ \\
\hline P8. * & $\begin{array}{l}\text { (i) Information } \\
\text { divulgations are } \\
\text { lacking. (ii) } \\
\text { Stakeholders lack a } \\
\text { clear message and } \\
\text { comprehension. }\end{array}$ & $\begin{array}{c}\text { (i) Starting } \\
\text { communication } \\
\text { between various } \\
\text { stakeholders and } \\
\text { departments of the } \\
\text { company (exchange } \\
\text { of elementary } \\
\text { information). }\end{array}$ & $\begin{array}{l}\text { (i) Average level of } \\
\text { information } \\
\text { disclosure, clarity, } \\
\text { and accuracy among } \\
\text { all the interested } \\
\text { parties. }\end{array}$ & $\begin{array}{l}\text { (i) High level of } \\
\text { information } \\
\text { disclosure, clarity, } \\
\text { and accuracy among } \\
\text { all the interested } \\
\text { parties (informal). }\end{array}$ & $\begin{array}{l}\text { (i) Formal disclosure } \\
\text { to all stakeholders } \\
\text { through complete } \\
\text { clarity as well as } \\
\text { accuracy of } \\
\text { information. }\end{array}$ & $\begin{array}{c}\text { [53-55], } \\
\text { (Section 2.1.8.) }\end{array}$ \\
\hline P9. * & $\begin{array}{l}\text { (i) Understand i4.0 } \\
\text { enablers. } \\
\text { (ii) Research on } \\
\text { technology } \\
\text { applications. }\end{array}$ & $\begin{array}{l}\text { (i) Promotion and } \\
\text { implementation of } \\
\text { i4.0 project for } \\
\text { digitalization } \\
\text { (hardware/software) }\end{array}$ & $\begin{array}{l}\text { (i) Average } \\
\text { digitalization of the } \\
\text { processes through the } \\
\text { product life cycle } \\
\text { (CAE). }\end{array}$ & $\begin{array}{l}\text { (i) Managerial } \\
\text { systems (e.g., ERP). } \\
\text { (ii) Smart factory } \\
\text { systems (MES) }\end{array}$ & $\begin{array}{c}\text { (i) Avant-garde } \\
\text { technology, as well as } \\
\text { a degree of } \\
\text { automation. (ii) } \\
\text { Extensive cover of } \\
\text { i4.0 enablers }\end{array}$ & $\begin{array}{c}{[56-58]} \\
\text { (Section 2.1.9.) }\end{array}$ \\
\hline P10. * & $\begin{array}{l}\text { (i) Senior leaders and } \\
\text { management } \\
\text { understand the } \\
\text { continuous } \\
\text { improvement } \\
\text { philosophy. } \\
\text { (ii) Awareness of } \\
\text { current situation }\end{array}$ & $\begin{array}{l}\text { (i) Study of tools and } \\
\text { techniques proposed } \\
\text { by continuous } \\
\text { improvement and } \\
\text { lean methodologies as } \\
\text { well (e.g.; } \\
\text { problem-solving). }\end{array}$ & $\begin{array}{l}\text { (i) Structured } \\
\text { objective, } \\
\text { goal-oriented } \\
\text { continuous } \\
\text { improvement. }\end{array}$ & $\begin{array}{c}\text { (i) Proactive } \\
\text { continuous } \\
\text { improvement, } \\
\text { including application } \\
\text { and monitoring of } \\
\text { lean tools and } \\
\text { methodologies. }\end{array}$ & $\begin{array}{l}\text { (i) Senior leaders } \\
\text { spread the continuous } \\
\text { improvement } \\
\text { philosophy and } \\
\text { methodologies } \\
\text { throughout the } \\
\text { organization. }\end{array}$ & $\begin{array}{c}{[51,59,61]} \\
\text { (Section 2.1.10.) }\end{array}$ \\
\hline
\end{tabular}

The maturity level/grade can be inferred by identifying the actual company state for each principle, using Table 2 . A fine tuning of the maturity percentage can be defined within each relative $20 \%$ discretization range.

\subsection{Alternative Mathematical Definition}

For four principles, (P3. to P6.) the following mathematical definitions are available in the literature.

\subsubsection{P3. Flexibility}

To evaluate volume and mix flexibility for each variant in the production system, a definite time frame $t$ must be fixed. During time $t$ for a specific product type $i$, it is possible to define the market demand $d_{t, i}$ and the quantity produced $p_{t, i}$. If the production system is not flexible enough to satisfy the customer demand for the product type $i$ during the time $t$, there will be a difference between $d_{t i I}$ and $p_{t, i}$. For a portfolio of $n$ different product types, the total deviation in units can be formally described by the Formula (1). 
Different product types typically require different specific resources. For this reason, a correction-weighting the deviations in volume according to their impact on capacity-is needed. $c_{i}$ is defined as the capacity demand for one unit of product type $i$ [48].

$$
F L E X_{t}=1-\frac{\sum_{i=1}^{n} c_{i}\left|d_{t, i}-p_{t, i}\right|}{\sum_{i=1}^{n} c_{i} \cdot d_{t, i}}
$$

\subsubsection{P4. Modularization}

The modularization function (2) decreases nonlinearly from a perfectly modular architecture (e.g., only standard, no new components) to a perfectly integral architecture (e.g., no standard components, only new ones).

$$
M(u)=e^{-\frac{u^{2}}{2 N s \delta}}
$$

where $M(u)$ is a modularization function of $u$, number of new components, $N$ is the total number of components, $s$, the substitutability factor, $\delta$, the interface constraints [49].

\subsubsection{P5. Continuous Process Flow}

The continuous process flow (WIP) is calculated in (3) as defined by [50]. The flow time, $F_{T}$, is the actual amount of time spent, and the cycle time, $C_{T}$ is the ideal time needed. The first term varies, the second is fixed.

$$
W I P={\frac{F_{T}}{C}}_{T}
$$

\subsubsection{P6. Demand Pull}

The pull degree, quantified in (4), was defined in [51]. This criterion is closely related to the CODP defined in Figure 1 and quantifies the ratio between the activities after the decoupling point, in contrast with the total number of phases in the product life cycle (Engineering, Purchasing, Assembly, Packaging and Delivery).

$$
\text { Pull Degree }=\frac{\text { Phases Pull Number }}{\text { Phase Total Number }}
$$

\section{Case Study}

Further guidelines for the model and method of application are presented here. The assessment tool was developed and tested on an Italian manufacturer of customized woodworking machines and lines in an ETO/MTO scenario.

Section 3.1 offers a validation of the tool, along with a more detailed guide to the practical evaluation of the principles whose mathematical formulas have been defined in Section 2.3.

Based on the evidence in Table 3, P10. *, continuous improvement was the weakest principle. For this reason, a set of steps followed in the continuous improvement path is presented in Section 3.2.

\subsection{Tool Validation}

The outcome of the application of the proposed tool is presented in Table 3. It shows the assessment evidence and evaluation. With respect to the four principles defined in Section 2.3, the mathematical evaluation and accompanying detailed guide in the use of its formulas can be found in Sections 3.1.1-3.1.4.

\subsubsection{P3. Flexibility}

As shown in Table 4 , the difference between market demands $d_{i}$ and product quantity $p_{i}$ is equal to 0 for each product type. Therefore, the Formula (1) results equal to 1. 
Table 3. The ten criteria, evaluated on a manufacturer of woodworking machines and lines in an ETO/MTO scenario. Maturity grades and scores are shown. In addition, all evidence for each principle has been summarized. $\left({ }^{*}\right)$ denotes principles where a mathematical formula is not defined.

\begin{tabular}{|c|c|c|c|}
\hline \multirow{2}{*}{ ETO Lean Principle } & \multirow{2}{*}{ Evidences } & \multicolumn{2}{|c|}{ Lean Maturity } \\
\hline & & Grade & Score \\
\hline P1. * & $\begin{array}{l}\text { Little clarity in the stakeholders' roles in the company } \\
\text { emerged. Absence of an organizational chart. }\end{array}$ & 2 & $30 \%$ \\
\hline P2. * & $\begin{array}{c}\text { The management is responsibly committed to the } \\
\text { achievement of goals and promotes active training on } \\
\text { the job. }\end{array}$ & 4 & $70 \%$ \\
\hline P3. & $\begin{array}{l}\text { The company adapts to customer requests easily. Result } \\
\qquad \text { from (1) } \\
\qquad F L E X_{t}=1\end{array}$ & 5 & $100 \%$ \\
\hline P4. & $\begin{array}{l}\text { The reuse of standard solutions or parts to produce } \\
\text { special machines is common practice. Result from (2) } \\
\qquad M(u)=0.8\end{array}$ & 5 & $80 \%$ \\
\hline P5. & $\begin{array}{l}\text { Result from (3) } \\
\qquad W I P=88 \%\end{array}$ & 5 & $88 \%$ \\
\hline P6. & $\begin{array}{l}\text { For the machines analyzed, the assembly process starts } \\
\text { after receiving the customer orders. Result from (4) } \\
\qquad \text { Pull Degree }=60 \%\end{array}$ & 4 & $60 \%$ \\
\hline P7. * & $\begin{array}{l}\text { The company consults the interested parties before } \\
\text { making decisions. Meetings are by department, not } \\
\text { collective. }\end{array}$ & 3 & $40 \%$ \\
\hline P8. * & $\begin{array}{l}\text { Average level of disclosure. There is no standard, tested } \\
\text { system for information disclosure. }\end{array}$ & 4 & $60 \%$ \\
\hline P9. * & $\begin{array}{l}\text { The company uses a specific management software } \\
\text { (anonymized). The management software includes the } \\
\text { customer orders, insertion of the bills of materials and } \\
\text { the purchase of the materials necessary for production. } \\
\text { Commercial CAD software is implemented. }\end{array}$ & 5 & $80 \%$ \\
\hline P10. * & $\begin{array}{l}\text { Senior leaders and management are aware of the } \\
\text { continuous improvement philosophy, but lean tools and } \\
\text { methods are not actually implemented. }\end{array}$ & 2 & $20 \%$ \\
\hline OVERALL & Ten criteria average value & 4 & $63 \%$ \\
\hline
\end{tabular}

Table 4. Four anonymized product types over a period of 2 months for the present case study. Market demand $\left(d_{i}\right)$ [count], quantity produced $\left(p_{i}\right)$ [count].

\begin{tabular}{ccc}
\hline Product Type & $\boldsymbol{d}_{\boldsymbol{i}}$ & $\boldsymbol{p}_{\boldsymbol{i}}$ \\
\hline Model A & 13 & 13 \\
Model B & 16 & 16 \\
Model C & 10 & 10 \\
Model D & 15 & 15 \\
\hline
\end{tabular}

\subsubsection{P4. Modularization}

The degree of modularization expressed in (2) was computed by approximating the product (Model A) as a reference for all the product types. The number of new and total components for Model A are, respectively, $u=12$ and $N=62$. With respect to substitutability, the value can be assumed as $s=1$ because of the possibility of replacing any new component with an old one. Finally, the interface constraint factor $\delta$ can be divided into two levels. At level 1:

$$
\delta_{1}=\delta_{\text {component }}+\delta_{\text {sub_circuit }}
$$


where $\delta_{\text {component }}$ in $(5)$ has been expressed as:

$$
\delta_{\text {component }}=\frac{\sum_{i=1}^{I} \delta_{i}}{I}
$$

where $I$ in (6) is the number of subcircuits and the interface constraint value is $\delta_{i}=\frac{\sum K_{c}}{n_{c}}$, with $K_{c}$ number of interfaces and $n_{c}$ is the number of components in a subcircuit. Regarding the subcircuits $\delta_{\text {sub_circuit }}$ :

$$
\delta_{\text {sub_circuit }}=\frac{\sum K_{\text {sub_circuit }}}{I}
$$

where $K_{\text {sub_circuit }}$ in (7) is the number of subcircuit interfaces. Using the data in Table 5: $\mathrm{I}=5 ; \delta_{\text {sub-circuit }}=1.4 ; \delta_{\text {component }}=5 ; \delta_{1}=6.4$.

Table 5. Manufacturing data collected for Model A at level 1. Number of interfaces $\left(K_{c}\right)$ [count], number of components in a sub-circuit $\left(n_{c}\right)$ [count], interface constraint value $\left(\delta_{i}\right)$ [count], number of sub-circuit interfaces $\left(K_{\text {sub_circuit }}\right)$ [count].

\begin{tabular}{ccccc}
\hline Subcircuits & $\boldsymbol{K}_{\boldsymbol{c}}$ & $\boldsymbol{n}_{\boldsymbol{c}}$ & $\boldsymbol{\delta}_{\boldsymbol{i}}$ & $\boldsymbol{K}_{\text {sub-circuits }}$ \\
\hline Micro & 4 & 1 & 4 & 1 \\
Vacuum Switch & 3 & 1 & 3 & 3 \\
Sensor & 3 & 1 & 3 & 1 \\
Big Case & 1 & 10 & 10 & 1 \\
Motor & 5 & 1 & 5 & 1 \\
\hline
\end{tabular}

At level 2:

$$
\delta_{2}=\sum_{j=1}^{N_{m}} \delta_{j}
$$

with $N_{m}$ in (8) is the number of total mechanical components and

$$
\delta_{j}=\frac{\sum K_{j}}{N_{j}}
$$

where $K_{j}$ in (9) is the number of interfaces for the subcircuits analyzed and $N_{j}$ is the number of mechanical components at the interface with the subcircuit. Using the data in Table 6, $\delta_{2}=6.75$.

Table 6. Manufacturing data collected for the product Model A at level 2. Number of interfaces for the analyzed subcircuits $\left(K_{j}\right)$ [count], number of mechanical components at the interface with the subcircuit $\left(N_{j}\right)$ [count].

\begin{tabular}{cccc}
\hline Mechanical Components & $K_{j}$ & $N_{j}$ & $\delta_{j}$ \\
\hline Forward Head & 26 & 13 & 2 \\
Rear Head & 15 & 10 & 1.5 \\
Vacuum Switch Support & 21 & 17 & 1.25 \\
Micro Support & 34 & 17 & 2 \\
\hline
\end{tabular}

Using the above results, $\delta_{\text {tot }}=\frac{\delta_{1}+\delta_{2}}{I}=2.63$, where $\delta_{\text {tot }}$ represents the interface constraint factor for one base of the product Model A. Therefore, the final $\delta_{\text {tot }}$ is multiplied by 2 . The final degree of modularization of the 12 new components, determined by applying (2), is $M(12)=0.8$.

\subsubsection{P5. Continuous Flow Process}

The Work in Progress (WIP) can be calculated, as in (3). In the present case study, the flow time $F_{T}$ and the cycle time $C_{T}$ are calculated referring to the product Model $\mathrm{A}$. 
In Table 7, daily data related to the product Model A (including the actual amount of production time (flow time)) are presented.

Table 7. Daily flow time $\left(F_{T}\right)[\mathrm{min}]$ data collected for 20 days for the product Model A.

\begin{tabular}{ccccccccccccccccccccc}
\hline Day & $\mathbf{1}$ & $\mathbf{2}$ & $\mathbf{3}$ & $\mathbf{4}$ & $\mathbf{5}$ & $\mathbf{6}$ & $\mathbf{7}$ & $\mathbf{8}$ & $\mathbf{9}$ & $\mathbf{1 0}$ & $\mathbf{1 1}$ & $\mathbf{1 2}$ & $\mathbf{1 3}$ & $\mathbf{1 4}$ & $\mathbf{1 5}$ & $\mathbf{1 6}$ & $\mathbf{1 7}$ & $\mathbf{1 8}$ & $\mathbf{1 9}$ & $\mathbf{2 0}$ \\
\hline$F_{T}$ & 560 & 600 & 605 & 660 & 590 & 585 & 540 & 705 & 645 & 580 & 650 & 560 & 565 & 575 & 555 & 710 & 540 & 625 & 565 & 685 \\
\hline
\end{tabular}

Based on the data presented in Table 7 , the average $F_{T}=12,095 /(60 \times 20)=10.1$ [h]. The calculated Cycle Time is $C_{T}=9\left[\frac{h}{p c s}\right]$. Finally, following (3), WIP $=1.12$ [pcs]. To evaluate the maturity level, an experimental conversion table was defined, as shown in Table 8.

Table 8. Conversion table of 1.12 in $88 \%$. The maturity is assumed as a linear with $F_{T}$, maximal when the $F_{T}=C_{T}$ and minimal when $F_{T}=2 C_{T}$.

\begin{tabular}{cc}
\hline Percentage [\%] & WIP [pcs] \\
\hline 100 & 1 \\
80 & 1.2 \\
60 & 1.4 \\
40 & 1.6 \\
20 & 1.8 \\
0 & 2 \\
\hline
\end{tabular}

The lean maturity score for the WIP in the present case study for the continuous flow process criterion $\cong 88 \%$.

\subsubsection{P6. Demand Pull}

The pull degree was calculated according to (4), where $P_{N}=3$ (assembly, packaging and delivery), the number of pull phases (after the decoupling point) and $P_{T o t}=5$, the total number of phases. Therefore, pull degree $=60 \%$. This parameter also shows that the examined company fell between pure ETO and make to order (MTO).

\subsection{Problem Solving}

As shown in Table 3, the organization had a critical lean maturity level, mainly on continuous improvement. As anticipated in [62], many small and medium-sized enterprises, like the present case study, often prefer to invest in quick high potential improvements (due to their limited resources) in their implementation of lean principles. For these companies, the focus should lie on low hanging fruits, including methods like continuous improvement, that can be introduced with minimal effort and generate maximal benefits.

Sections 3.2.1-3.2.6 describe the main steps followed on the continuous improvement implementation path, based on a systematic problem-solving approach which included some common lean tools. In particular, VSM, the 5 whys, and the new PFM (described in Section 3.2.5) were applied in a DMAIC (define, measure, analyze, improve, control) cycle [63], revised according to the framework in Figure 4 and detailed here.

\subsubsection{Problem Identification}

To identify all the problems, briefing activities were carried out. These included: (i) procedure definition, (ii) data collection sheet definition, (iii) audit, and (iv) noncompliance (NC) data collection. The most effective tool used in this phase was a noncompliance checklist designed for data collection. 


\subsubsection{Problem Prioritization and Selection}

After listing and prioritizing the identified problems according to a Pareto chart cumulating the recurrence, the most frequent one was selected: incomplete thread of the support housing screw.

\subsubsection{Problem Definition}

In this phase, regarding the problem (incomplete thread of the support housing screw), the process focusing on the interested station was analyzed. The value stream mapping (VSM) tool was applied to the process flow diagram to detect possible inefficiencies or wastes. It highlighted how the retapping of the thread occurred, after an initial tapping by the supplier. This repeated tapping was identified as a possible source of inefficiency because it added no value.

\subsubsection{Problem Analysis}

In this phase, the causes of the selected NC were investigated by applying the classical lean 5 whys tool, as shown in Figure 5. Starting from the circumscribed problem identified in Section 3.2.3, five "Why?" questions were asked, in an effort to determine the root causes. The first question in the chain was: why re-tapping the thread?

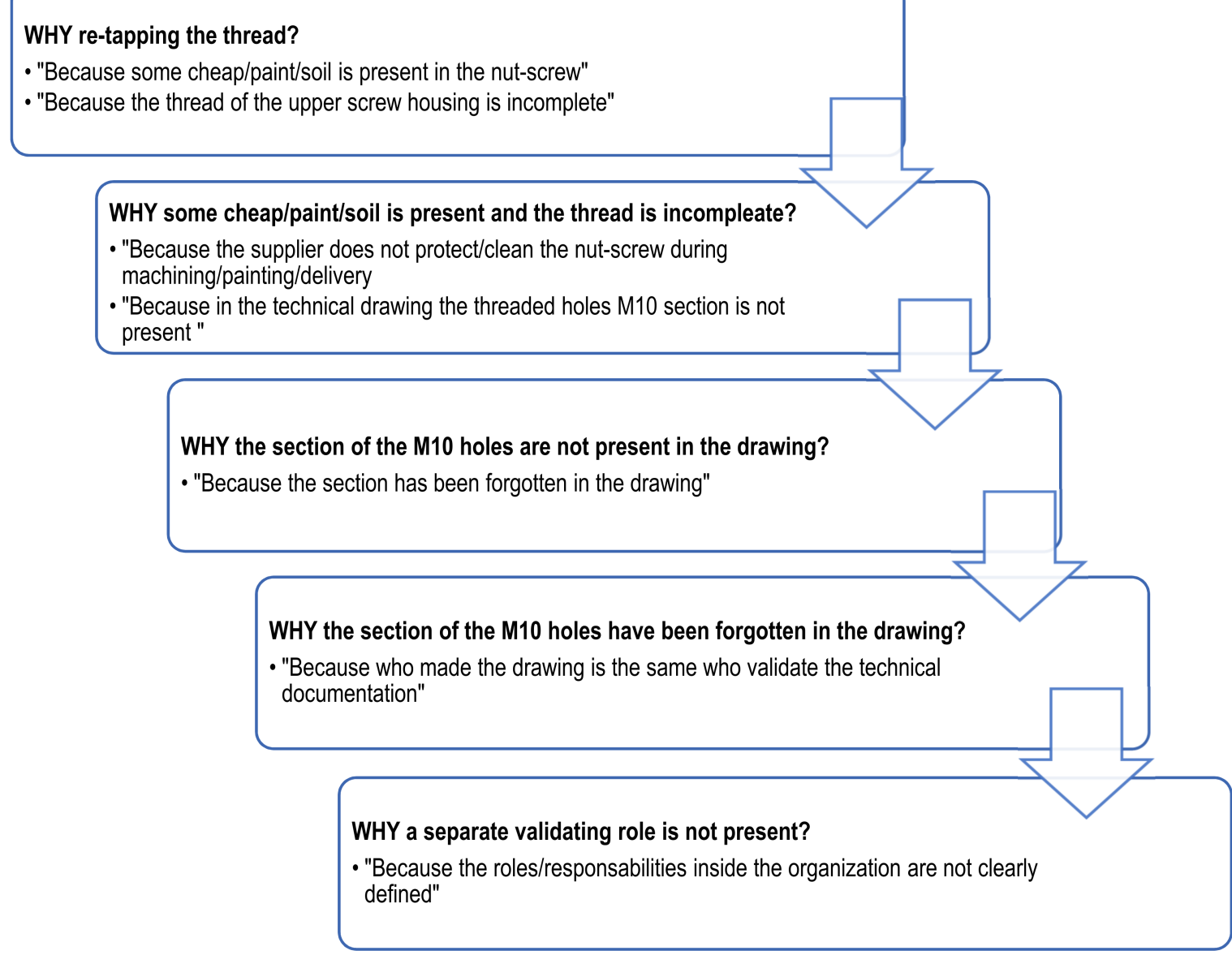

Figure 5. The lean 5 whys tool, applied. The answers collected during the interview sessions are shown below each question.

The two identified root causes:

(a) External: generated by the supplier (because the supplier does not protect/clean properly the nut-screw during manufacturing/painting/delivery).

(b) Internal: generated by the technical office (because the section of the M10 holes is not present in the technical drawing). 


\subsubsection{Focus Definition}

To face the two identified root causes, a graphic new lean tool for strategy implementation is proposed in Figure 6: the problem focusing matrix (PFM).

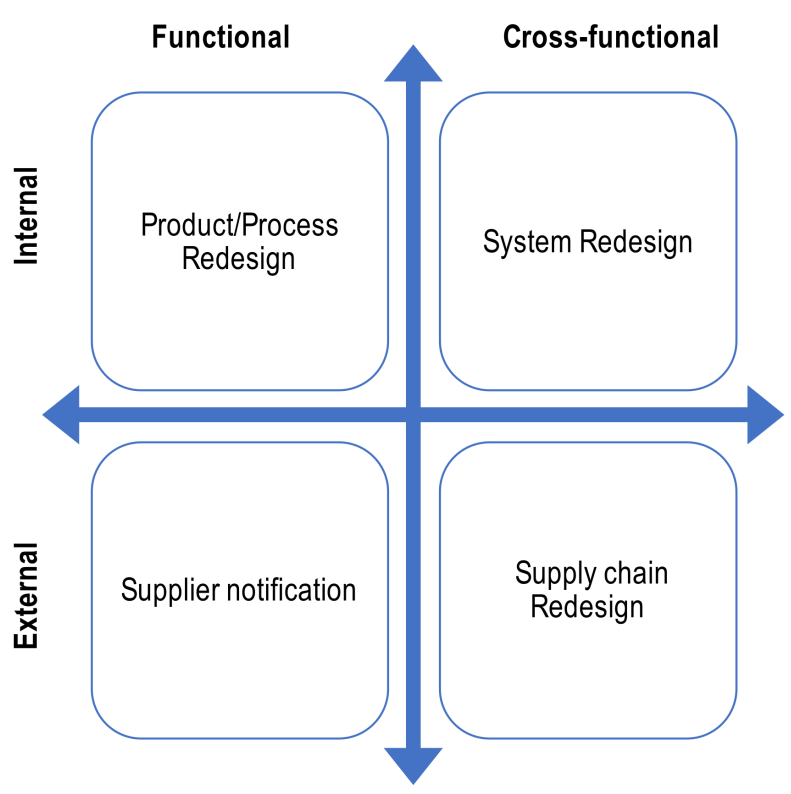

Figure 6. Proposed problem focusing matrix (PFM): the focus can be internal or external to the organization and it can be focused (functional/operative) or defocused to include multiple functions (cross-function/systemic action).

In the case of a specific problem, like that in the present case study, the functional area that suggests lighter strategies was considered. If the problem affected the whole organization, systemic action would need to be considered.

For example, in the case of external/cross-functional systemic problems, the theory introduced by Kraljic [64] as well as Olsen and Ellram [65] required more attention, in contrast with smaller, easy-to-solve problems.

Focusing on the two root causes identified in Section 3.2.4,

In cause (a), the team is basically functional and focused on the manufacturing area. The problem is caused by an external issue: the supplier. In this scenario, the suggested strategy is supplier notification.

In cause (b), the team is basically functional and focused on the manufacturing area. The problem is caused by an internal issue. The head of the department decides how to solve and eventually redesign the process/product.

\subsubsection{Solution Implementation}

To remove the root causes, the PFM defined in Section 3.2.5 can be used as follows:

(a) "The supplier does not properly protect/clean the nut-screw during manufacturing/painting/delivery". Solution: in the case of an external and circumscribed problem like this, the resolution is a simple notification to the supplier to request a preventive action for the regenerating of that NC. Improved communication could help speed up this process.

(b) "The section of the M10 holes is not present in the technical drawing": Solution: Focusing on the internal cause, two actions were adopted: the correction of the technical drawing, and the removal of the root cause- the absence of defined roles/responsibilities. The responsible-accountable-consultant-informed (RACI) tool was a simple and effective way to avoid the repetition of similar issues caused by the absence of formal separation of duties inside the company. 


\section{Results}

The application of the proposed assessment criteria in Table 2 to the examined case provided the evidence and the grades/scores shown in Table 3, and visually represented by a radar graph in Figure 7.

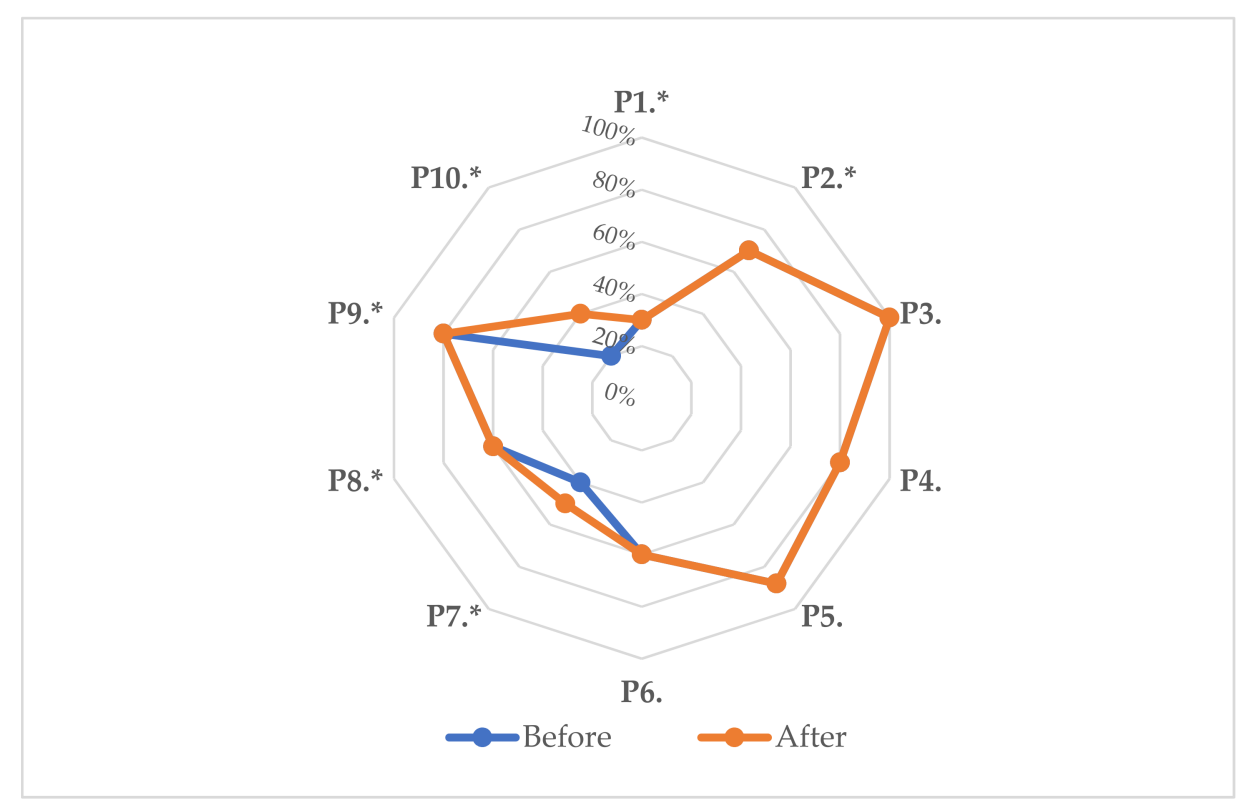

Figure 7. Radar graph with the lean maturity grades/scores for the present case study. Before data are taken from Table 4 (blue); After data resulted from the application of the solutions in Section 3.2.6 (orange). $\left(^{*}\right)$ denotes a principle whose mathematical definition is lacking.

The management of the real ETO industrial company involved in this project identified the priority of investing in the weakest principle, as determined by the analysis in Table 3: continuous improvement.

It was clear that continuous improvement tools and techniques positively affected the following principles:

P10. *: direct effect on continuous improvement, increasing from grade 2 to grade 3 (from $20 \%$ to $40 \%$ );

P7. *: indirect positive effect on the stakeholders and system integration principles (from $40 \%$ to $50 \%$ ).

Among the numerous lean tools used in the problem-solving process, the VSM and the 5 whys enabled the identification of a source of waste in the production process. By removing the no-value-added activity of retapping, $25 \mathrm{~min}$ were deducted from the total station time of $\sim 45 \mathrm{~min}$ (or $\sim 55 \%$ of the station time).

After the adoption of these improvements, the new overall score on the ten principles increased from $63 \%$ to $66 \%$. The objective improvement after repeating the assessment was clear, and can be considered as a validation of the proposed method.

\section{Discussion}

The presented model is a systematic and easily-implemented tool for ETO companies wishing to move toward lean manufacturing. It offers an objective look at their lean manufacturing maturity level and a way to define improvement paths.

From Figure 7, it can be observed that the ten principles are not completely independent. In particular, continuous improvement indirectly affects stakeholders and system integration (and, to a lesser extent, other principles). Surveys on clusters of ETO manufacturers (e.g., in geographic areas or within specific sectors) may infer statistical evidence to refine the proposed assessment model. 
Interferences among other principles were observed, but their low significance did not allow a generalization to be drawn from the examined case. Extensive application in surveys on ETO industrial compartments, company sizes, geographic areas, etc., may infer interferences among lean principles (e.g., leadership and others).

Regarding the stakeholders and system integration principle: the application of the strategies shown in Figure 5 to the two root causes of the proposed matrix enriched a classic problem-solving approach. Namely:

- In (a), it facilitated collaboration within the company throughout the value chain.

- The use of the responsible-accountable-consultant-informed (RACI) tool in (b) defined

roles and responsibilities within the organization matrix by focusing on the interested parties within the organization.

Regarding lean maturity and the seven kinds of waste [21,22]: the $55 \%$ reduction of one production station's time falls under the waiting time waste class. A formal relationship between the proposed model and the waste to be eliminated is a possible future development.

The current model includes the definition of objective parameters for all the ETO lean principles. Additional mathematical formulas can be included and further refined for a more detailed assessment, e.g., a synthetic method for people management [66], smart sensor outputs [67], and supply chain integration [68].

In Figure 8, a hierarchical representation of the developed model is provided. The principles and criteria have been defined in cascade.

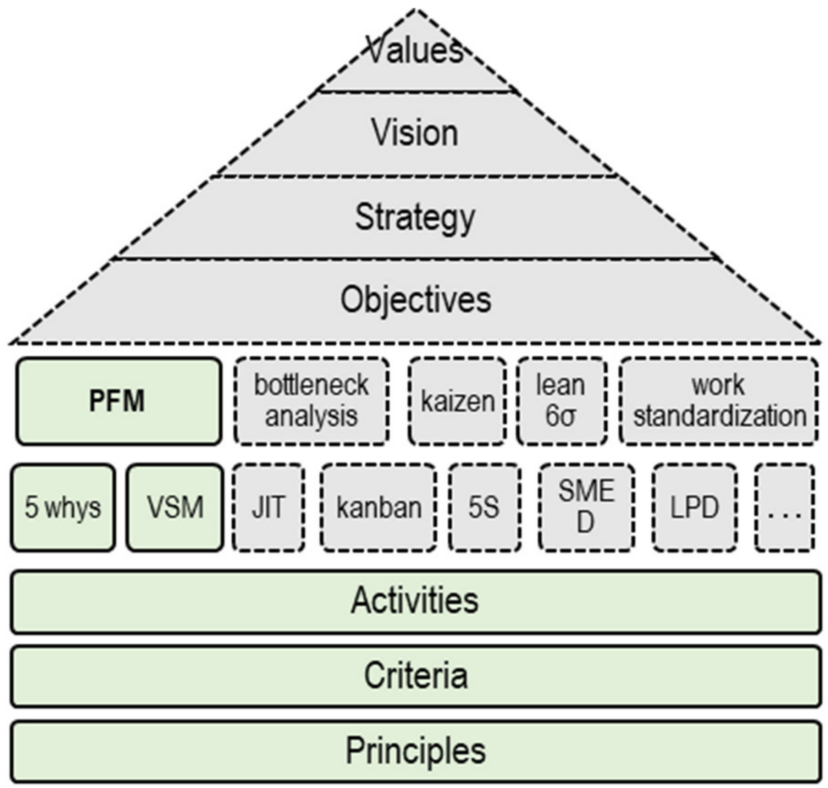

Figure 8. The proposed model is the base to achieve the organizational mission by lean tools enablers. The principles and the assessment tool allow the definition of improvement activities. Light green items have been developed in this work, including the new (bold) PFM lean tool, while grey and dotted areas can be addressed in future research.

Once the assessment process has been carried out, the resulting evidence can be used as a starting point for improvement activities. The problem-solving approach in Section 3.2 is an example of activity. Figure 8 represents a systematic framework to integrate lean production and the mission of the organization, by exploiting the building blocks represented by the lean tools (exploded in the middle). This area connects the assessment framework and the strategic management.

Further works would help in defining a comprehensive assessment tool focused onto ETO lean practices with direct connections to the elements of the pyramid above. Similar 
connections were found in the European Foundation for Quality Management (EFQM) model $[34,69]$, the Baldrige award, and the Deming price, which provide a systematic perspective for a future lean ETO award. Such standardized framework may adopt specific lean tools and techniques, e.g., poke-yoke, JIT, SMED, 5S, TPM, and others. An example was provided within the proposed problem-solving approach, including two lean tools (VSM, 5 whys and PFM).

One weak point in the present work is model generalization. The application of the proposed method to a statistically significant number of applications is required.

\section{Conclusions}

The assessment model presented in this work offered an overall view of lean maturity (from a comprehensive and systematic approach) in an ETO scenario.

The aim of this work was to offer a practical tool that could be easily implemented by ETO manufacturers for as-is mapping and weakness identification. Additionally, the tool would enable monitoring of the manufacturers' achieved maturity of lean principles.

This work identified ten dominating lean principles from the restricted literature on lean ETO. These principles were further defined through further analysis of the literature that was not specific to ETO. An assessment model for lean ETO maturity was not available and was thus defined by quantitative criteria on five levels, grades, and scores. Four criteria were associated to mathematical formulas.

The real case study presented showed, in detail, the practical application of the lean maturity assessment model, serving as a step toward validation of the proposed model. The problem-solving approach (based on the evidence uncovered during the assessment step) represented a step toward a structured framework to connect the organization mission and management via existing lean tools (VSM and 5 whys) and a newly developed one (PFM).

The proposed method led to more research questions than answers. These have been extensively discussed above.

Among the dominating lean principles in ETO, continuous improvement deserved particular attention, and showed a positive impact on other principles.

A double nested virtual improvement cycle was identified for the proposed model and the lean improvement path.

Author Contributions: Conceptualization, M.L. and M.C.; methodology, F.L. and M.L.; software, M.C.; validation, F.L. and M.L.; formal analysis, F.L.; investigation, M.C.; resources, M.C.; data curation, M.C.; writing-original draft preparation, M.C.; writing—review and editing, F.L., A.R. and M.L.; visualization, F.L.; supervision, M.L.; project administration, M.L. All authors have read and agreed to the published version of the manuscript.

Funding: This research received no external funding.

Institutional Review Board Statement: Not applicable.

Informed Consent Statement: Not applicable.

Data Availability Statement: Not applicable.

Conflicts of Interest: The authors declare no conflict of interest.

\section{References}

1. Womack, J.P.; Jones, D.T.; Roos, D. The Machine That Changed the World; Free Press: Washington, DC, USA, $1992 ;$ Volume 35. [CrossRef]

2. Bhamu, J.; Sangwan, K.S. Lean Manufacturing: Literature Review and Research Issues. In International Journal of Operations and Production Management; Emerald Group Publishing Ltd.: Bingley, UK, 2014; pp. 876-940. [CrossRef]

3. Toyota Production System: Beyond Large-Scale Production-Taiichi Ohno. Available online: https://books.google.it/books? $\mathrm{hl}=\mathrm{it \& l} \mathrm{lr}=\& \mathrm{id}=7$-67SshOy8C\&oi=fnd\&pg=PR9\&ots=YpRxz9wcDZ\&sig=UIHS3U_qLIireW7mspYhdunOJ2w\&redir_esc=y\#v= onepage\&q\&f=false (accessed on 24 March 2021).

4. Basu, R. Six Sigma to Fit Sigma. IIE Solut. 2001, 33, 28-33. 
5. Dahlgaard, J.J.; Dahlgaard-Park, S.M. Lean Production, Six Sigma Quality, TQM and Company Culture. TQM Mag. 2006, 18, 263-281. [CrossRef]

6. Sundar, R.; Balaji, A.N.; Satheesh Kumar, R.M. A Review on Lean Manufacturing Implementation Techniques. In Procedia Engineering; Elsevier Ltd: Amsterdam, The Netherlands, 2014; Volume 97, pp. 1875-1885. [CrossRef]

7. Sugimori, Y.; Kusunoki, K.; Cho, F.; Uchikawa, S. Toyota Production System and Kanban System Materialization of Just-in-Time and Respect-for-Human System. Int. J. Prod. Res. 1977, 15, 553-564. [CrossRef]

8. Yazdani, B. Toyota Production System: An Integrated Approach to Just-in-Time; CRC Press: Boca Raton, FL, USA, 1995 ; Volume 8. [CrossRef]

9. Perico, P.; Arica, E.; Powell, D.J.; Gaiardelli, P. MES as an Enabler of Lean Manufacturing. IFAC-PapersOnLine 2019, 52, 48-53. [CrossRef]

10. Susaki, K. New Manufacturing Challenge: Techniques for Continuous Improvement. Available online: https://books.google.it/ books?hl=it\&lr=\&id=6EHtJE8NHD0C\&oi=fnd\&pg=PR11\&ots=BMlbLEXGjX\&sig=a-iDbwTHa5JFKRHhku40ABGBc0s\&redir_ $\mathrm{esc}=\mathrm{y} \# \mathrm{v}=$ onepage \&q\&f=false (accessed on 24 March 2021).

11. Acero, R.; Torralba, M.; Pérez-Moya, R.; Pozo, J.A. Value Stream Analysis in Military Logistics: The Improvement in Order Processing Procedure. Appl. Sci. 2020, 10, 106. [CrossRef]

12. Kumar Sharma, R.; Gopal Sharma, R. Integrating Six Sigma culture and TPM framework to improve manufacturing performance in SMEs. Qual. Reliab. Eng. Int. 2014, 30, 745-765. [CrossRef]

13. Ikumapayi, O.M.; Akinlabi, E.T.; Mwema, F.M.; Ogbonna, O.S. Six Sigma versus Lean Manufacturing-An Overview. In Materials Today: Proceedings; Elsevier Ltd: Amsterdam, The Netherlands, 2019; Volume 26, pp. 3275-3281. [CrossRef]

14. Sodhi, H.S.; Singh, D.; Singh, B.J. A Conceptual Examination of Lean, Six Sigma and Lean Six Sigma Models for Managing Waste in Manufacturing SMEs. World J. Sci. Technol. Sustain. Dev. 2020, 17, 20-32. [CrossRef]

15. Monteiro, C.; Ferreira, L.P.; Fernandes, N.O.; Sá, J.C.; Ribeiro, M.T.; Silva, F.J.G. Improving the Machining Process of the Metalworking Industry Using the Lean Tool SMED. In Procedia Manufacturing; Elsevier B.V.: Amsterdam, The Netherlands, 2019; Volume 41, pp. 555-562. [CrossRef]

16. Leming-Lee, T.S.; Polancich, S.; Pilon, B. The Application of the Toyota Production System LEAN 5S Methodology in the Operating Room Setting. Nurs. Clin. N. Am. 2019, 54, 53-79. [CrossRef]

17. Lyu, Z.; Lin, P.; Guo, D.; Huang, G.Q. Towards Zero-Warehousing Smart Manufacturing from Zero-Inventory Just-In-Time Production. Robot. Comput. Integr. Manuf. 2020, 64, 101932. [CrossRef]

18. Amrani, A.; Ducq, Y. Lean Practices Implementation in Aerospace Based on Sector Characteristics: Methodology and Case Study. Prod. Plan. Control 2020, 31, 1313-1335. [CrossRef]

19. Marodin, G.; Frank, A.G.; Tortorella, G.L.; Netland, T. Lean Product Development and Lean Manufacturing: Testing Moderation Effects. Int. J. Prod. Econ. 2018, 203, 301-310. [CrossRef]

20. Domingo, R.T. Identifying and Eliminating the Seven Wastes or Muda; Asian Institute of Management: Makati, Philippines, 2003.

21. Realyvásquez-Vargas, A.; Arredondo-Soto, K.C.; Carrillo-Gutiérrez, T.; Ravelo, G. Applying the Plan-Do-Check-Act (PDCA) Cycle to Reduce the Defects in the Manufacturing Industry. A Case Study. Appl. Sci. 2018, 8, 2181. [CrossRef]

22. Vinodh, S.; Arvind, K.R.; Somanaathan, M. Tools and Techniques for Enabling Sustainability through Lean Initiatives. Clean Technol. Environ. Policy 2011, 13, 469-479. [CrossRef]

23. Gehin, A.; Zwolinski, P.; Brissaud, D. A Tool to Implement Sustainable End-of-Life Strategies in the Product Development Phase. J. Clean. Prod. 2008, 16, 566-576. [CrossRef]

24. Yadav, G.; Luthra, S.; Huisingh, D.; Mangla, S.K.; Narkhede, B.E.; Liu, Y. Development of a Lean Manufacturing Framework to Enhance Its Adoption within Manufacturing Companies in Developing Economies. J. Clean. Prod. 2020, 245, 118726. [CrossRef]

25. Henao, R.; Sarache, W.; Gómez, I. Lean Manufacturing and Sustainable Performance: Trends and Future Challenges. J. Clean. Prod. 2019, 208, 99-116. [CrossRef]

26. Melton, T. The Benefits of Lean Manufacturing: What Lean Thinking Has to Offer the Process Industries. Chem. Eng. Res. Des. 2005, 83, 662-673. [CrossRef]

27. Azzi, A.; Battini, D.; Faccio, M.; Persona, A. Mixed model assembly system with multiple secondary feeder lines: Layout design and balancing procedure for ATO environment. Int. J. Prod. Res. 2012, 50, 5132-5151. [CrossRef]

28. Olhager, J. Strategic Positioning of the Order Penetration Point. In International Journal of Production Economics; Elsevier: Amsterdam, The Netherlands, 2003; Volume 85, pp. 319-329. [CrossRef]

29. García, J.G.; Gallego-García, S.; García-García, M. Development of a Pull Production Control Method for ETO Companies and Simulation for the Metallurgical Industry. Appl. Sci. 2020, 10, 274. [CrossRef]

30. Powell, D.; Strandhagen, J.O.; Tommelein, I.; Ballard, G.; Rossi, M. A New Set of Principles for Pursuing the Lean Ideal in Engineer-To-Order Manufacturers. In Procedia CIRP; Elsevier B.V.: Amsterdam, The Netherlands, 2014; Volume 17, pp. 571-576. [CrossRef]

31. Wang, W.; Khalid, Q.S.; Abas, M.; Li, H.; Azim, S.; Babar, A.R.; Saleem, W.; Khan, R. Implementation of POLCA Integrated QRM Framework for Optimized Production Performance-A Case Study. Sustainability 2021, 13, 3452. [CrossRef]

32. Schulze, F.; Dallasega, P. Barriers to lean implementation in engineer-to-order manufacturing with subsequent assembly on-site: State of the art and future directions. Prod. Plan. Control 2021, 1-25. [CrossRef] 
33. Moradi-Moghadam, M.; Safari, H.; Maleki, M. A Novel Model for Business Process Maturity Assessment through Combining Maturity Models with EFQM and ISO 9004: 2009. Int. J. Bus. Process Integr. Manag. 2003, 6, 167-184. [CrossRef]

34. Bou-Llusar, J.C.; Escrig-Tena, A.B.; Roca-Puig, V.; Beltrán-Martín, I. An Empirical Assessment of the EFQM Excellence Model: Evaluation as a TQM Framework Relative to the MBNQA Model. J. Oper. Manag. 2009, 27, 1-22. [CrossRef]

35. Doolen, T.L.; Hacker, M.E. A Review of Lean Assessment in Organizations: An Exploratory Study of Lean Practices by Electronics Manufacturers. J. Manuf. Syst. 2005, 24, 55-67. [CrossRef]

36. Pakdil, F.; Leonard, K.M. Criteria for a Lean Organisation: Development of a Lean Assessment Tool. Int. J. Prod. Res. 2014, 52, 4587-4607. [CrossRef]

37. Ali Almomani, M.; Abdelhadi, A.; Mumani, A.; Momani, A.; Aladeemy, M. A Proposed Integrated Model of Lean Assessment and Analytical Hierarchy Process for a Dynamic Road Map of Lean Implementation. Int. J. Adv. Manuf. Technol. 2014, 72, 161-172. [CrossRef]

38. Cil, I.; Turkan, Y.S. An ANP-Based Assessment Model for Lean Enterprise Transformation. Int. J. Adv. Manuf. Technol. 2013, 64, 1113-1130. [CrossRef]

39. Nightingale, D.; Mize, J. Development of a Lean Enterprise Transformation Maturity Model. Inf. Knowl. Syst. Manag. 2002, 3, $15-30$.

40. Initiative, L.A. LAI Enterprise Self-Assessment Tool (LESAT) V.2 Facilitator's Guide; MIT: Cambridge, MA, USA, 2012.

41. Kumar, M.; Vaishya, R. Real-Time Monitoring System to Lean Manufacturing. In Procedia Manufacturing; Elsevier B.V.: Amsterdam, The Netherlands, 2018; Volume 20, pp. 135-140. [CrossRef]

42. International Standard ISO Quality Management-Quality of an Organization-Guidance to Achieve Sustained Success. Available online: https://www.iso.org/obp/ui/\#iso:std:iso:9004:ed-4:v1:en (accessed on 7 February 2021).

43. Krijnen, A. The Toyota Way: 14 Management Principles from the World's Greatest Manufacturer. Action Learn. Res. Pract. 2007, 4, 109-111. [CrossRef]

44. Koskela, L.J. Application of the New Production Philosophy to Construction Construction Management in Refurbishment Projects View Project Energy and Cost Efficient Design of Buildings View Project; Stanford University: Stanford, CA, USA, 2018.

45. The Toyota Product Development System: Integrating People, Process, and ... -James Morgan, Jeffrey, K. Liker-Google Libri. Available online: https:/ / books.google.it/books?hl=it\&lr=\&id=K0EHEAAAQBAJ\&oi=fnd\&pg=PT12\&ots=viri-SUuWu\&sig= p-tbKsDErG504m7WBTMZRqVTops\&redir_esc=y\#v=onepage\&q\&f=false (accessed on 27 March 2021).

46. Earl, G.; Clift, R. Stakeholder Value Analysis: A Methodology for Intergrating Stakeholder Values into Corporate Enviromental Investment Decisions. Bus. Strateg. Environ. 1999, 8, 149-162. [CrossRef]

47. Hamidi, S.R.; Aziz, A.A.; Shuhidan, S.M.; Aziz, A.A.; Mokhsin, M. SMEs Maturity Model Assessment of IR4.0 Digital Transformation. In Advances in Intelligent Systems and Computing; Springer: Berlin/Heidelberg, Germany, 2018; Volume 739, pp. 721-732. [CrossRef]

48. Mettemich, J.; Böllhoff, J.; Seifeimami, S.; Beck, S. Volume and Mix Flexibility Evaluation of Lean Production Systems. Procedia CIRP 2013, 9, 79-84. [CrossRef]

49. Mikkola, J.H. Mdoularization Assesment of Product Architecture. In Proceedings of the DRUID Winter Conference, Frederiksberg, Denmark, 7-8 January 2000.

50. Storch, R.L.; Lim, S. Improving Flow to Achieve Lean Manufacturing in Shipbuilding. Prod. Plan. Control 1999, 10, 127-137. [CrossRef]

51. Karlsson, C.; Hlström, P. Assessing Changes towards Lean Production. In International Journal of Operations and Production Management; MCB UP Ltd: Bingley, UK, 1996; pp. 24-41. [CrossRef]

52. Plaza-Úbeda, J.A.; de Burgos-Jiménez, J.; Carmona-Moreno, E. Measuring Stakeholder Integration: Knowledge, Interaction and Adaptational Behavior Dimensions. J. Bus. Ethics 2010, 93, 419-442. [CrossRef]

53. Holland, D.; Krause, A.; Provencher, J.; Seltzer, T. Transparency Tested: The Influence of Message Features on Public Perceptions of Organizational Transparency. Public Relat. Rev. 2018, 44, 256-264. [CrossRef]

54. Kundeliene, K.; Leitoniene, S. Business Information Transparency: Causes and Evaluation Possibilities. Procedia Soc. Behav. Sci. 2015, 213, 340-344. [CrossRef]

55. Christensen, L.T.; Cheney, G. Peering into Transparency: Challenging Ideals, Proxies, and Organizational Practices. Commun. Theory 2015, 25, 70-90. [CrossRef]

56. Zhong, R.Y.; Xu, X.; Klotz, E.; Newman, S.T. Intelligent Manufacturing in the Context of Industry 4.0: A Review. Engineering 2017, 3, 616-630. [CrossRef]

57. Vinodh, S.; Kuttalingam, D. Computer-Aided Design and Engineering as Enablers of Agile Manufacturing: A Case Study in an Indian Manufacturing Organization. J. Manuf. Technol. Manag. 2011, 22, 405-418. [CrossRef]

58. Powell, D.; Riezebos, J.; Strandhagen, J.O. Lean Production and ERP Systems in Small- and Medium-Sized Enterprises: ERP Support for Pull Production. Int. J. Prod. Res. 2013, 51, 395-409. [CrossRef]

59. ISO-ISO 9001:2015-Quality Management Systems-Requirements. Available online: https://www.iso.org/standard/62085.html (accessed on 13 February 2021).

60. Jagtap, M.; Teli, S.N. PDCA Cycle as TQM Tool-continuous improvement of warranty. Int. J. Recent Technol. Mech. Electr. Eng. (IJRMEE). 2015, 2, 1-5. 
61. Caffyn, S. Development of a Continuous Improvement Self-Assessment Tool. Int. J. Oper. Prod. Manag. 1999, 19, 1138-1153. [CrossRef]

62. Rauch, E.; Dallasega, P.; Matt, D.T. Critical Factors for Introducing Lean Product Development to Small and Medium Sized Enterprises in Italy. In Procedia CIRP; Elsevier B.V.: Amsterdam, The Netherlands, 2017; Volume 60, pp. 362-367. [CrossRef]

63. De Mast, J.; Lokkerbol, J. An analysis of the Six Sigma DMAIC method from the perspective of problem solving. Int. J. Prod. Econ. 2012, 139, 604-614. [CrossRef]

64. Montgomery, R.T.; Ogden, J.A.; Boehmke, B.C. A Quantified Kraljic Portfolio Matrix: Using Decision Analysis for Strategic Purchasing. J. Purch. Supply Manag. 2018, 24, 192-203. [CrossRef]

65. Olsen, R.F.; Ellram, L.M. A Portfolio Approach to Supplier Relationships. Ind. Mark. Manag. 1997, 26, 101-113. [CrossRef]

66. Lanzetta, M.; Rossi, A.; Puppato, A. Modelling activity times by hybrid synthetic method. Prod. Plan. Control 2016, 27, 909-924. [CrossRef]

67. Rossi, A.; Vila, Y.; Lusiani, F.; Barsotti, L.; Sani, L.; Ceccarelli, P.; Lanzetta, M. Embedded smart sensor device in construction site machinery. Comput. Ind. 2019, 108, 12-20. [CrossRef]

68. Faccio, M.; Persona, A.; Sgarbossa, F.; Zanin, G. Multi-stage supply network design in case of reverse flows: A closed-loop approach. Int. J. Oper. Res. 2011, 12, 157-191. [CrossRef]

69. Wongrassamee, S.; Simmons, J.E.L.; Gardiner, P.D. Performance measurement tools: The Balanced Scorecard and the EFQM Excellence Model. Meas. Bus. Excell. 2003, 7, 14-29. [CrossRef] 